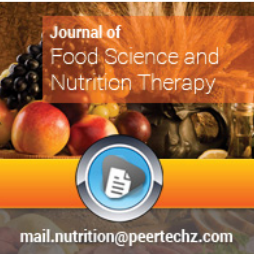

\title{
Journal of Food Science and Nutrition Therapy
}

Zehra Güler ${ }^{*}$, Ali Tekin ${ }^{1}$ and Young W Park $^{2}$

'Mustafa Kemal University, Faculty of Agriculture, Department of Food Engineering, 31034-AntakyaHatay, Turkey

${ }^{2}$ Georgia Small Ruminant Research \& Extension Center, Fort Valley State University, Fort Valley, USA

Dates: Received: 02 December, 2016; Accepted: 12 December, 2016; Published: 13 December, 2016

*Corresponding author: Zehra Güler, Mustafa Kemal University, Faculty of Agriculture, Department of Food Engineering, 31034-Antakya-Hatay, Turkey, Tel: +903262455844/1055; Fax: +903262455832; E-mail: zguler@mku.edu.tr; zehra_guler@yahoo.com.tr

Keywords: Kefir; Organic acids; Volatile compounds; Amino acids

https://www.peertechz.com
Research Article

\section{Comparison of Biochemical Changes} in Kefirs Produced from Organic and Conventional Milk at Different Inoculation Rates of Kefir Grains

\section{Introduction}

Kefir is a fermented milk product which contains high ethanol and $\mathrm{CO}_{2}$ contents, and has characteristics of sharp acidic taste and yeasty flavour. The word kefir is derived from Turkish language which means "feel good" [1]. For traditional kefir production, kefir grains are directly added to pasteurized milk at $20-25{ }^{\circ} \mathrm{C}$ and incubated for $18-22 \mathrm{~h}$. After incubation, kefir grains are removed from the fermented milk for re-use. Kefir grains contain mainly lactic acid bacteria ( $L b$. kefiranofaciens and Lb. kefir), acetic acid bacteria and yeasts (Kluyveromyces lactis, Kluyveromyces marxianus, Torula kefir, Saccharomyces cerevisiae) in a protein and polysaccharide matrix which provide fermentation of the product [2].

Due to symbiotic metabolic activity of bacteria and yeasts in microbial flora of kefir grains, kefir has both a unique flavour and complex probiotic properties when compared with yogurt. Lactose fermentation and lactic acid assimilation, lipolysis and proteolysis are important reactions of microbial flora in kefir grains which are responsible for the diverse flavour compounds such as ethanol, $\mathrm{CO}_{2}$, lactic acid, acetic acid, pyruvic acid and diacetyl reported in kefir [3-6]. The numbers and concentrations of volatile organic compounds, organic acids and free amino acids are responsible for kefir flavour, which are mainly dependent on the ratio of kefir grains added to milk, type of milk used and source of grains $[3,6,7]$. The effects of two different rates ( $1 \%$ and $5 \%$ ) of inoculation of kefir grains on microbiological, basic physicochemical and sensory characteristics of the kefir products have been studied [8]. However, to our knowledge, no studies have been available on determination of volatile organic compounds (VOCs), organic acids and free amino acids (FAAs) of kefir made from organic cow milk in comparison with conventional cow milk using kefir grains at different ratios are available in literature. In Turkey the conventional milk compared to organic milk, is very cheap and widely used for home-made kefir using kefir grains as inoculate.

Therefore, the objective of our study was to compare organic cow milk with conventional cow milk with respect to biochemical changes in VOCs, organic acids and FAAs as well as basic chemical composition and overall acceptability of kefir manufactured using two different rates of inoculation of kefir

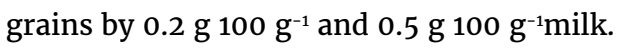




\section{Material and Methods}

\section{Experimental design}

The study was conducted in a $3 \times 2 \times 2$ factorial experiment. Three batches of Kefir were manufactured using organic and conventional UHT cow milks. Two levels of Kefir grains as 0.2

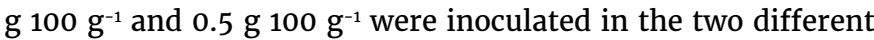
milks. Analyses of all experimental data were determined in duplicates.

\section{Preparation of kefir grains and milks}

Kefir grains were provided from Ankara University, Department of Dairy Science (Ankara, Turkey). Certificated organic and conventional UHT (Ultra High Temperature) cow's milk with the same brand was obtained from a retail market at Antakya, Hatay, Turkey.

\section{Preparation of chemicals}

Organic acid, amino acid, glucose, galactose and lactose standards were purchased from Sigma-Aldrich $\mathrm{GmbH}$ (Steinheim, Germany), Fluka (Buchs, France) and Supelco (Bellefonte, PA, USA). The authentic standards of volatile organic compounds were obtained from Merck (Hohenbrunn, Germany) and Fluka, Sigma-Aldrich (Switzerland).

\section{Manufacture of experimental kefirs}

The experimental Kefirs were made using the traditional kefir production method by inoculating the Kefir grains directly the two types of milk. Kefir grains were inoculated at

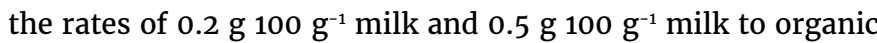
and conventional cow milks at $25^{\circ} \mathrm{C}$. Samples were coded as

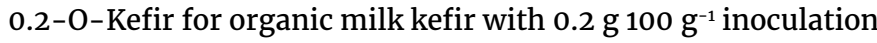

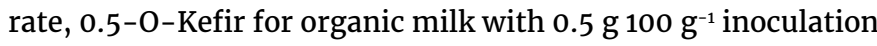

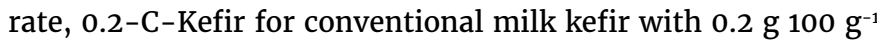
inoculation rate and $0.5-\mathrm{C}$-Kefir for conventional milk kefir

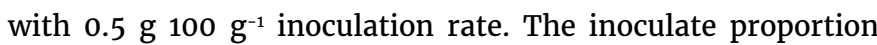
of kefir grains was decided after preliminary sensory studies for kefir made from organic cow milk. After incubation at $25^{\circ} \mathrm{C}$ for 20-24 h to $\mathrm{pH} 4.5$, the grains were separated from the fermented milk by filtration through a sieve and were washed with cooled sterile water before they were used for the next kefir production. All produced kefir samples were taken into glass jars (500 g) and stored at $4^{\circ} \mathrm{C}$. After one day, the kefir samples were analyzed for biochemical and sensory analysis.

\section{Nutritional and biochemical analyses}

Basic nutrients and $\mathbf{p H}$ analyses: The total solids, fat, ash and acidity as lactic acid of the kefir samples were analyzed according to methodology recommended by the Association of Official Analytical Chemist Methods [9]. The $\mathrm{pH}$ was measured using a $\mathrm{pH}$ meter (Orion, Thermo, Beverly, MA, USA). Total nitrogen was measured by the micro-Kjeldahl method [10], using the Gerhardt KB $40 \mathrm{OS}$ digestion and Vapotest distillation systems (C.Gerhardt, Bonn, Germany).
Organic acids and carbohydrates analyses: Organic acids and carbohydrates were analyzed according to the procedure by Fernandez-Garcia \& McGregor [11] in an automated HPLC system (HPLC-20 AD Prominence, Shimadzu, Kyoto, Japan) using an ione exchance column (Aminex HPX-87 H, $300 \times 7.8 \mathrm{~mm}$, BIO-RAD, Hercules, CA, USA). Organic acids and carbohydrates were detected at $210 \mathrm{~nm}$ with a UV/VIS detector (SPD-20 AV, Shimadzu, Kyoto, Japan) and refractive Index detector (RID-10A, Shimadzu, Kyoto, Japan), respectively. Linear regression curves based on peak areas were calculated for the individual organic acid and carbohydrate covering a broad range of concentrations.

Volatile compounds analysis: The extraction and characterization of the volatile compounds were carried out by headspace (HS)/solid phase micro-extraction (SPME)/ Gas Chromatography (GC)/Mass Spectrometry (MS) analysis, which were able to detect the most volatile compounds. Ten $\mathrm{g}$ of the kefir samples were immediately transferred in $20 \mathrm{~mL}$ head space vial containing $2 \mathrm{~g} \mathrm{NaCl}$ (Agilent, USA). The vials were sealed using crimp-top caps with TFE/silicone headspace septa (Agilent, USA) and immediately frozen at $-20^{\circ} \mathrm{C}$ until use. Prior to analysis, frozen samples were thawed at $4^{\circ} \mathrm{C}$ overnight. At the time of solid phase micro-extraction analysis, the vials were placed in a water bath with temperature control and stirring. The sample vials were equilibrated for $30 \mathrm{~min}$ at $60^{\circ} \mathrm{C}$ in water bath then a $70 \mu \mathrm{m}$ Carboxen/PDMS (Supelco, Bellefonte PA.,USA) fibre was exposed to the sample headspace for $40 \mathrm{~min}$ at $60^{\circ} \mathrm{C}$. Several preliminary tests were carried out to optimize solid phase micro-extraction (SPME) system. Identification and calculation of volatile compounds were performed according to procedure described by Güler et al. [12] and Güler and Gürsoy-Balcı [13], respectively.

Amino acids composition analysis: Amino acid composition was analyzed by high performance liquid chromatography (HPLC-20 AD Prominence, Shimadzu, Kyoto, Japan) using method advised by the manufacturer (Shimadzu) with the modifications proposed by Aristoy and Toldrá [14], which involves pre-column derivatization with phenylisothiocyanate. Separation and detection were carried out with Mediterranea Sea 18 column ( $3 \mu \mathrm{m} 15 \mathrm{~cm}$ x 0,46 cm, Teknokroma, Barcelona, Spain) and UV detector at $254 \mathrm{~nm}$ (SPD-20 AV, Shimadzu, Kyoto, Japan), respectively. Solvents used for the separation were: sodium phosphate buffer $\mathrm{pH} 7.0$ (solvent $\mathrm{A}$ ) and acetonitrile (solvent B). Gradient conditions were: initial= $100 \% \mathrm{~A}, 1 \mathrm{~min}=$ $95 \% \mathrm{~A}, 5 \mathrm{~min}=, 90 \% \mathrm{~A}, 12 \mathrm{~min}=65 \% \mathrm{~A}, 16 \mathrm{~min}=55 \% \mathrm{~A}, 19 \mathrm{~min}=$ $30 \% \mathrm{~A}, 24.01 \mathrm{~min}=95 \% \mathrm{~A}$. HPLC oven temperature was $40^{\circ} \mathrm{C}$ and total flow rate of solvent was $0.9 \mathrm{~mL} / \mathrm{min}$. The working solutions of amino acid standards were prepared at the six different concentrations. Linear regression curves based on peak areas were calculated for the individual amino acids.

Sensory analysis: Sensory quality and acceptability of all experimental kefir samples were analyzed by 15 panellists. By using a 9-point hedonic sale ( 1 = dislike extremely, 5 = neither like nor dislike, 9 = like extremely), the sensory scores of the kefir products were evaluated for overall acceptability for the samples with respect to taste, odor and appearance. 


\section{Statistical analysis}

SPSS computer program (version 17.0 for windows) was used for statistical processing [15]. Effects of the types of milk as well as inoculation rate on chemical and biochemical parameters and overall sensory acceptability were evaluated by Bonferroni Repeated-Measures Analysis of Variance. The paired comparisons of means were performed using the Duncan mean comparison test $(P \leq 0.05)$.

\section{Results and Discussion}

\section{Basic chemical composition}

Although incubation time did not have any effect on the type of milk, it was significantly $(P \leq 0.05)$ influenced by the

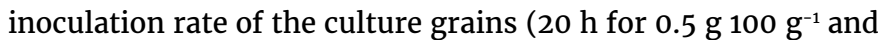

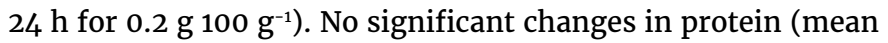
value of $\left.31.2 \pm 0.12 \mathrm{~g} \mathrm{~kg}^{-1}\right)$, fat $\left(31.5 \pm 0.14 \mathrm{~g} \mathrm{~kg}^{-1}\right)$, ash $(8.2 \pm 0.06$ $\left.\mathrm{g} \mathrm{kg}^{-1}\right)$ and $\mathrm{pH}(4.48 \pm 0.84)$ of kefir samples were observed. These values were similar with findings of Irigoyen et al. [8] and Wszolek et al. [16]. However, total titratable acidity of 0.2-O-Kefir was significantly $(P \leq 0.05)$ lower with value of $5.7 \pm 0.03 \mathrm{~g} \mathrm{~kg}^{-1}$ than $0.2-\mathrm{C}-$ Kefir (value of $6.2 \pm 0.03 \mathrm{~g} \mathrm{~kg}^{-1}$ ) and 0.5 -C-Kefir $\left(6.7 \pm 0.01 \mathrm{~g} \mathrm{~kg}^{-1}\right)$. This could be attributed to the increase in lactic acid content of kefir as result of the activity of kefir grains depending on milk medium. Titratable acidities of kefir samples were close to the minimum value ( $6 \mathrm{~g} \mathrm{~kg}^{-1}$ kefir) requiring for kefir [7].

\section{Carbohydrate and organic acid contents}

As shown in Table 1, the total carbohydrate concentrations of kefir samples ranged from $50.33 \mathrm{~g} \mathrm{~kg}^{-1}$ to $54.84 \mathrm{~g} \mathrm{~kg}^{-1} \mathrm{kefir}$.

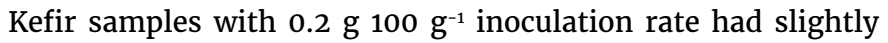

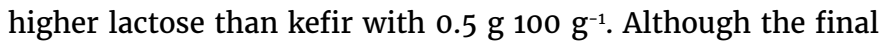
$\mathrm{pH}$ values of kefir samples were similar to each other, this could be attributed to the fermentation time of kefir made

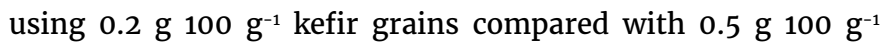
ratio since a long time $(24 \mathrm{~h})$ for fermentation at $25^{\circ} \mathrm{C}$ were critical for kefiran production [16]. Regardless of inoculation rate of kefir grains, organic milk kefir had significantly $(P \leq$ 0.05) higher carbohydrate than conventional milk kefir. This could be related to the less conversion of lactose to lactic acid and initial carbohydrate content of milk since lactose in milk medium improved to production of exopolysaccharide kefiran [16]. Total carbohydrate concentrations of kefir samples were

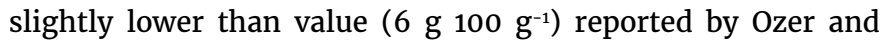
Ozer [17]. In contrast of previous findings [8,18], glucose concentration (range value of $1.72-1.95 \mathrm{~g} \mathrm{~kg}^{-1}$ ) was higher in all the samples than the values $\left(0.20-0.25 \mathrm{~g} \mathrm{~kg}^{-1}\right)$ of galactose. This could be due to the assimilation of galactose as carbon source by kefir grains microbiota to production of kefiran since some yeast species such as Saccharmyces boulardii are able to assimilate galactose instead of lactose [19].

Organic acid concentrations of kefir samples are presented in Table 1. As expected, primary organic acid was lactic acid, ranging from $6.43 \mathrm{~g} \mathrm{~kg}^{-1}$ to $8.31 \mathrm{~g} \mathrm{~kg}^{-1}$ kefir. Uric and pyruvic acids were found to be at the lowest concentrations compared with the other acids. Except for uric and formic acids, the other organic acids determined in this study were significantly $(P \leq 0.05)$ influenced by milk used for kefir-manufacturing. This could be attributed to the initial carbohydrate and citrate concentrations of milk since organic milk with high lactose and probably citrate proved to high succinic, acetic, propionic and pyruvic acid concentrations in kefir made from organic milk compared with conventional milk. This finding indicated that the metabolic pathway in organic milk kefir was in favour of acetic acid bacteria and /or heterofermentative lactic acid bacteria since lactic acid content of organic milk kefir was significantly $(P \leq 0.05)$ lower than that of conventional milk kefir. Kefir samples had the lower lactic, acetic and propionic acids and the higher citric acid concentrations than findings

Table 1: Carbohydrate and organic acid concentrations $\left(\mathrm{g} \mathrm{kg}^{-1}\right)$ of Kefir samples made using kefir grains at different proportions. $($ Values are means $\pm S D)$, ( $\left.\mathrm{n}=6\right)$

\begin{tabular}{|c|c|c|c|c|c|c|c|}
\hline & $0.2-0$ Kefir\$ & 0.5-0 Kefir§ & $P \neq$ & 0.2-C Kefir $\ddagger$ & 0.5-C Kefir & $P \neq$ & Pt \\
\hline \multicolumn{8}{|l|}{ Carbohydrates } \\
\hline Lactose & $52.79 \pm 0.15$ & $51.98 \pm 0.60$ & NS & $50.67 \pm 1.8$ & $48.30 \pm 0.7$ & NS & * \\
\hline Glucose & $1.80 \pm 0.01$ & $1.72 \pm 0.01$ & NS & $1.95 \pm 0.06$ & $1.81 \pm 0.02$ & NS & NS \\
\hline Galactose & $0.25 \pm 0.02$ & $0.20 \pm 0.01$ & * & $0.21 \pm 0.02$ & $0.22 \pm 0.006$ & NS & NS \\
\hline Total & 54.84 & 53.89 & & 52.82 & 50.33 & & \\
\hline \multicolumn{8}{|l|}{ Organic acids } \\
\hline Citric & $1.02 \pm 0.08$ & $1.00 \pm 0.06$ & NS & $0.57 \pm 0.04$ & $0.62 \pm 0.04$ & NS & $\star \star$ \\
\hline Pyruvic (mg kg-1) & $7.19 \pm 0.93$ & $17.19 \pm 1.75$ & $\star \star$ & $6.46 \pm 1.12$ & $4.38 \pm 0.38$ & * & $\star \star$ \\
\hline Uric $\left(\mathrm{mg} \mathrm{kg}^{-1}\right)$ & $3.56 \pm 0.88$ & $3.78 \pm 0.86$ & NS & $4.03 \pm 0.8$ & $3.64 \pm 0.82$ & NS & NS \\
\hline Succinic & $0.22 \pm 0.09$ & $0.26 \pm 0.03$ & $\star \star$ & $0.15 \pm 0.03$ & $0.20 \pm 0.02$ & * & * \\
\hline Lactic & $6.43 \pm 0.023$ & $6.70 \pm 0.058$ & * & $7.42 \pm 0.19$ & $8.31 \pm 0.08$ & * & * \\
\hline Formic & $1.10 \pm 0.36$ & $1.16 \pm 0.29$ & NS & $1.17 \pm 0.20$ & $1.07 \pm 0.15$ & NS & NS \\
\hline Acetic & $0.35 \pm 0.01$ & $0.38 \pm 0.01$ & NS & $0.29 \pm 0.02$ & $0.29 \pm 0.03$ & NS & * \\
\hline Propionic & $0.22 \pm 0.001$ & $0.22 \pm 0.00$ & NS & $0.15 \pm 0.02$ & $0.16 \pm 0.02$ & NS & $\star \star$ \\
\hline Total & 9.34 & 9.74 & & 9.77 & 10.64 & & \\
\hline
\end{tabular}

$\S$, Kefir produced from organic milk inoculated $0.2 \%$ and $0.5 \%$ kefir grains as culture; $¥$ Kefir produced from conventional milk; $\neq$ Significance at between inoculate ratios; †Significance at between milk variaties; NS, not significant, ${ }^{*} P \leq 0.05,{ }^{* \star} P \leq 0.01$. 
of Irigoyen et al. [8] and Leite et al. [18]. This may be due to the low inoculation rate and grains origin. Formic and succinic acids were found for the first time in kefir. Organic milk kefir with high citric acid contained significantly $(P \leq 0.05)$ high succinic acid when compared with conventional milk kefir. This result confirmed that succinic acid could be formed as a consequence of citrat metabolism by yeasts and probably some heterofermentative Lactobacillus strains since yeasts such as S. cerevisiae disrupting in succinate dehydrogenase enzyme in the absence of oxygen can dramatically accumulate succinate via citrate [20]. Regardless of the variety of milk, inoculation rate of kefir grains resulted in significant $(P \leq 0.05, P \leq 0.01)$ increases in lactic and succinic acids.

\section{Variations in the volatile organic compound (VOCs)}

Atotal of 19VOCs were identified by SPME/GC/MS: 5 benzenecontaining compounds, 6 acids, 4 ketones, 2 alcohols, 1 ester and 1 aldehyde (Figure 1). Volatile compound profiles of kefir samples were similar each other. Most of these compounds can derive from more than one metabolic pathway; precursors may be amino acids derived from proteolysis as well as fatty acids from lipolysis or carbohydrates (lactose, citrate, and lactate) [21]. As presented in Figure 1a, acetaldehyde, ethanol, ethyl acetate and pentanol were significantly $(P \leq 0.05)$ influenced by the both inoculation rate of kefir grains and the variety of milk. Ethanol was primary volatile compound, ranging from $0.24 \mathrm{~g}$ $\mathrm{kg}^{-1}$ to $0.29 \mathrm{~g} \mathrm{~kg}^{-1}$ kefir. An increase in kefir grains as inoculate resulted in increases in acetaldehyde, ethanol and ethyl acetate concentrations. This could be attributed to the increase in yeast number in kefir grains since they can form as secondary metabolite from yeast growth $[6,8]$. The levels of acetaldehyde, ethanol and ethyl acetate were lower than the values obtained from kefir made using $5 \%$ and $3 \%$ kefir grains as inoculate by Magalhães et al. [22] and Leite et al. [18], respectively.

As for ketones (Figure 1b), inoculation rate of kefir grains did not significantly effect on ketone concentrations of kefir samples. However, ketones 2-heptanone and 2-nonanone which originate from the oxidation of the FFA (octanoic and decanoic acids, respectively) by microbial metabolism [23] were significantly $(P \leq 0.01)$ higher in organic milk kefir samples than conventional milk kefir. Acetoin concentrations of kefir samples were slightly lower than that reported by Grønnevik et al. [6], but both acetoin and diacetyl were higher than values found by Aghlara et al. [5] and Beshkova et al. [4]. This could be attributed to the kefir grains origin, their inoculation rate, use of kefir grains, mother culture or bulk culture as starter and kefir manufacturing conditions. Diacetyl content in all the samples was considerably lower than acetoin, which could be reduced to acetoin by the microbial flora in kefir grains.

Although milk samples used for kefir manufacturing had similar fat concentrations ( $30 \mathrm{~g} \mathrm{~kg}^{-1}$ ), fatty acids concentrations, that is, lipolysis was significantly higher in conventional milk kefir than in organic milk kefir (Figure 1c). Higher $\mathrm{C}_{4}$ and $\mathrm{C}_{6}$ fatty acid concentrations in conventional milk kefir could be related to the action of both lipoprotein lipase (LPL) and microbial lipases or initial high fatty acids; in particular, LPL shows specificity toward sn-3 position of triacylglycerides, in which short-chain fatty acids (SCFA) are predominantly esterified [23].

Higher concentrations (with value of $0.66 \mathrm{~g} \mathrm{~kg}^{-1}$ ) of benzen-containing compounds were found in conventional milk kefir (Fig.1.d). Aromatic hydrocarbons do not make a major contribution to aroma, although they may serve as precursor for the formation of other aromatic compounds. Phenyl derivatives and styrene can be formed from amino acids like Phe and Tyr by Strecker degradation [21] or benzene and toluen are a normal component of milk [24] and also could originate from the degradation of the carotene in the milk [25]. Higher content of phenyl ethanol found in organic milk kefir was consistent with the higher content of the corresponding amino acid Phe found in its. The inoculation rate of kefir grains affected significantly $(P \leq 0.05)$ benzene derivatives in conventional milk whereas it did not effect on those, except for benzeneethanol, in organic milk kefir. This could be related to the microbial activity in kefir grains depending on initial milk media.

\section{Free amino acid (FAA) contents}

The changes in FAAs are shown in Figure 2. From a quantitative point of view, proline (range in values of 1219-1352 mmol kg-1), alanine $\left(394-544 \mathrm{mmol} \mathrm{kg}^{-1}\right)$, asparagine (457$\left.485 \mathrm{mmol} \mathrm{kg}^{-1}\right)$, lysine $\left(472-501 \mathrm{mmol} \mathrm{kg}^{-1}\right)$, arginine (364-586 mmol kg-1), cysteine $\left(314-569 \mathrm{mmol} \mathrm{kg}^{-1}\right)$, tyrosine (340-392 $\mathrm{mmol} \mathrm{\textrm {kg } ^ { - 1 }}$ ) and valine (223-374 $\left.\mathrm{mmol} \mathrm{kg}^{-1}\right)$, glutamine (240$296 \mathrm{mmol} \mathrm{kg}^{-1}$ ) were found to be the major FAAs in all the kefir samples. Liutkevicius and Sarkinas [26] reported the presence of mainly tryptophan, valine, lysine, methionine, phenylalanine, threonine, and isoleucine in fermented kefir. The main amino acids in kefir samples are presumably not required by the lactic acid bacteria and yeasts and/or they can be produced from proteins by acetic acid bacteria and yeasts with existence lactic acid and thus accumulate in larger quantities in kefir samples [27]. There are some conflicting reports on the distribution of free amino acids in kefir in terms of their amounts. Grønnevik et al. [6] found that glutamic acid was the most abundant amino acid in kefir. According to Simova et al. [28], Lactobacillus bulgaricus HP1 and Lactobacillus helveticus MP12 isolated from kefir starter had produced mainly proline as well as glutamic acid, and alanine was the second most abundant amino acid. This could be attributed to the origin of grains, the variety of milk and inoculation rate of grains depending on milk medium since proline, tyrosine, cysteine and valin amino acids increased significantly $(P \leq 0.05)$ in $0.5-C$-Kefir compared with the other kefir samples. Regardless of inoculation rate of grains, organic milk kefir had arginine, alanine, glycine, leucine amino acids at significantly $(P \leq 0.05)$ higher levels, and asparagine, valine, cysteine and tryptophan at lower levels than conventional milk kefir. Glutamic acid and methionine, is derived from cysteine and also aspartate, were no detected in organic milk kefir. Glutamic acid can be decarboxylated to $\gamma$-aminobutyric acid (GABA) during fermentation [29]. The initial concentration of methionine can be low in organic milk since both methionine and cystein, and also aspartate were high in conventional kefir. Total free amino acid content with the mean value of $0.0072 \mathrm{~g}$ 
(A)

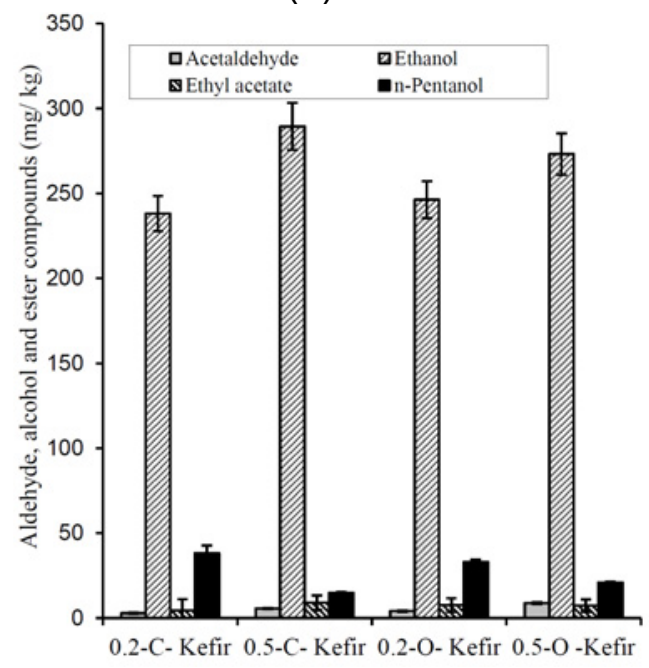

(C)

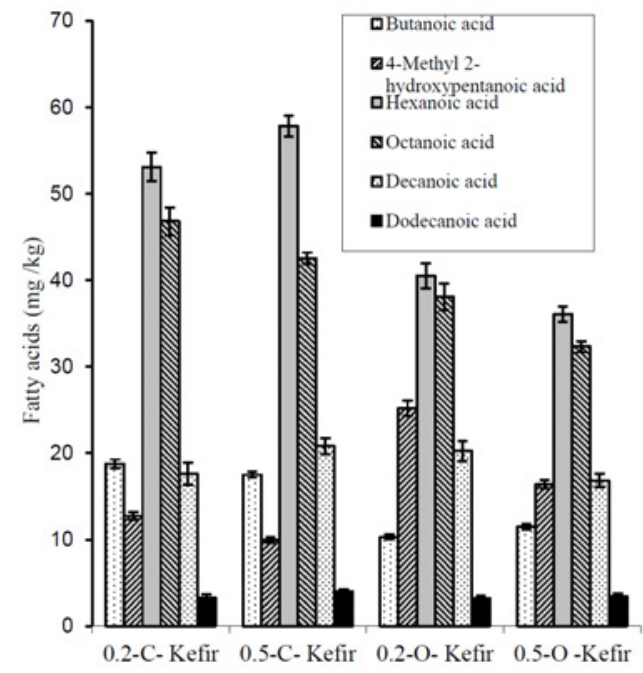

(B)

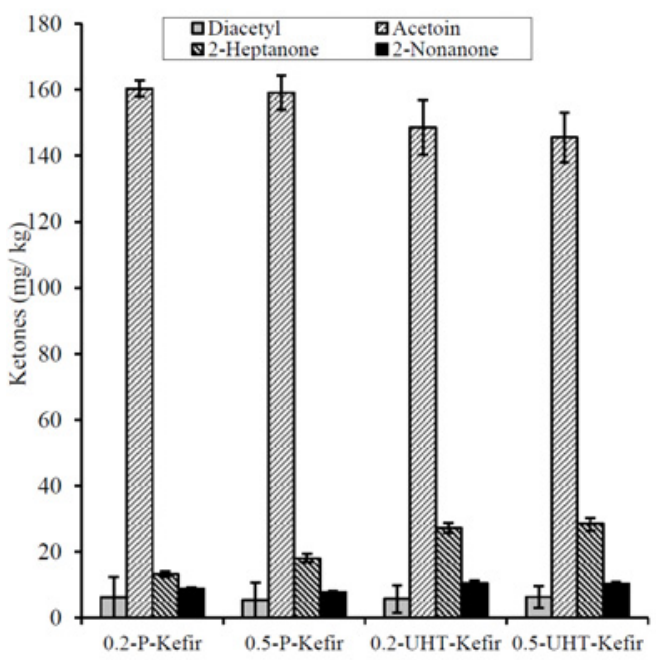

(D)

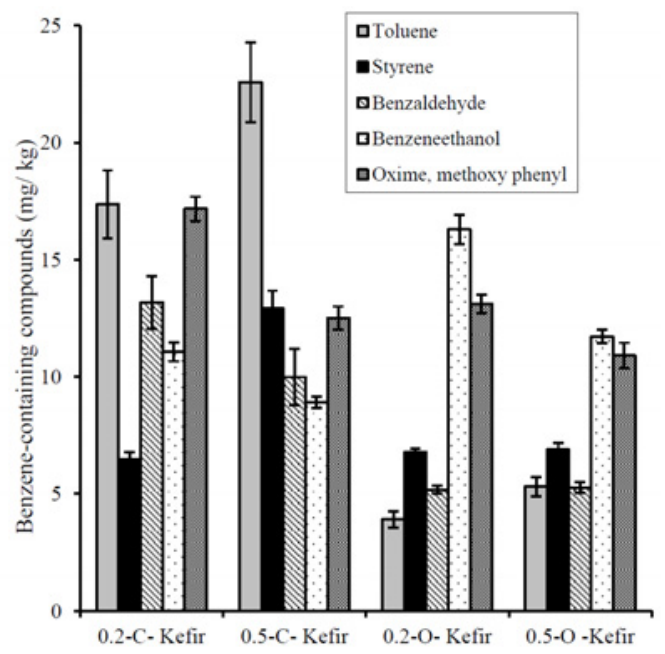

Figure 1: Volatile organic compounds ( $\mathrm{g} \mathrm{kg}^{-1}$ ) of Kefir samples. (a) Aldehydes, alcohols and ester compounds; (b) Ketones; (c) Fatty acids; (d) Benzene-containing compounds. 0.2-C-Kefir: Kefir made from conventional milk using $0.2 \mathrm{~g} 100 \mathrm{~g}^{-1}$ inoculation rate of kefir grains; 0.5-C-Kefir: Kefir made from conventional milk with $0.5 \mathrm{~g}$

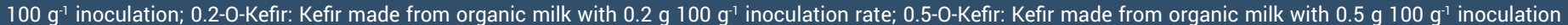
rate. Values are mean and bars show SD for $n=6$.

$\mathrm{kg}^{-1}$ was higher in conventional milk kefir than that $(0.0063 \mathrm{~g}$ $\mathrm{kg}^{-1} \mathrm{kefir}$ ) in organic milk kefir. This result was consistent with titratable acidity since fermented milk products with higher lactic acid concentrations are proved to high amino acid levels [27]. Total free amino acid concentrations of kefir samples in present study were higher than value $\left(0.0057 \mathrm{~g} \mathrm{~kg}^{-1}\right)$ reported by Simova et al. [28].

\section{Overall sensory acceptability}

On account of sensory analysis, kefir made from organic milk with $0.2 \%$ inoculation rate was obtained the highest score (with value of $7.4 \pm 1.3$ ) by the panellists, followed by 0.5 - O-Kefir (5.5 \pm 0.6$), 0.5$-C-Kefir $(4.6 \pm 0.8)$ and 0.2-C-Kefir (3.4 \pm 1.2$)$. The panelists preferred kefir with low lactic acid $\left(6.43 \mathrm{~g} \mathrm{~kg}^{-1}\right)$, butanoic acid $\left(0.001 \mathrm{~g} \mathrm{~kg}^{-1}\right)$, toluen $\left(0.0044 \mathrm{~g} \mathrm{~kg}^{-}\right.$ $\left.{ }^{1}\right)$, total FAA (0.006 $\left.\mathrm{g} \mathrm{kg}^{-1}\right)$, and high total carbohydrate $(54.84$ $\left.\mathrm{g} \mathrm{kg}^{-1}\right)$, when compared with the other kefir samples. It is noteworthy that these chemical parameters may be essential for kefir overall acceptability.

\section{Conclusions}

Biochemical changes in kefir samples at the end of the fermentation process showed that differences were dependent on the types of milk and inoculation rate of kefir grains. Effect of inoculation rate on biochemical changes was more pronounced in conventional milk than that in organic milk. Regardless of inoculation rate of kefir grains, the organic milk kefir had higher acetic, pyruvic, succinic and propionic organic acids, but lower lactic acid than the conventional milk kefirs. Panelists preferred the organic milk kefir made using $0.2 \mathrm{~g} 100$ $\mathrm{g}^{-1}$ kefir grains due probably to low organic acid and total free amino acid, and high carbohydrate concentrations. Further study may be needed to determine microbial identification and its count in kefir samples as a long-term goal of this research. 


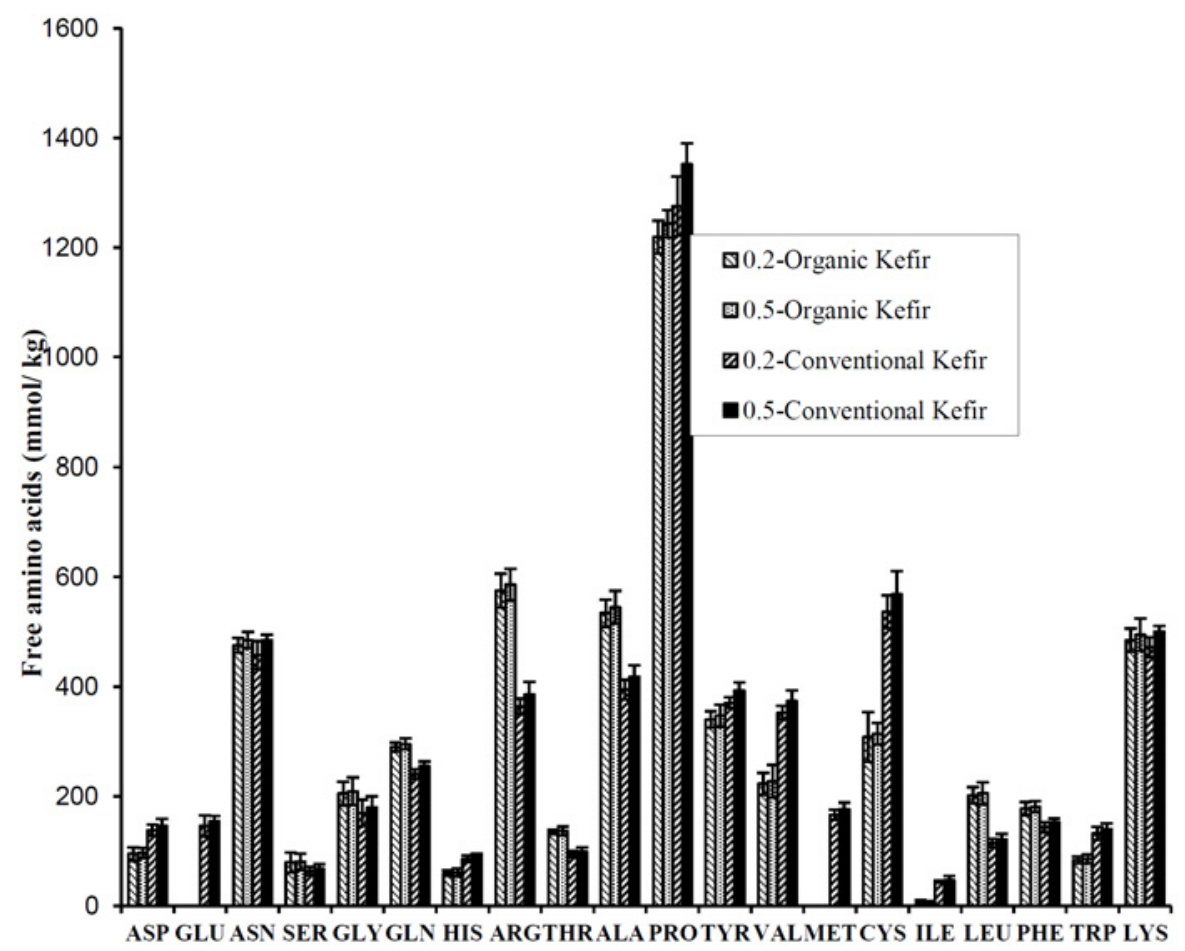

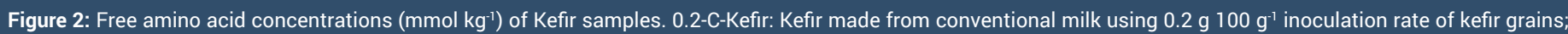
0.5-C-Kefir: Kefir made from conventional milk with $0.5 \mathrm{~g} 100 \mathrm{~g} \mathrm{~g}^{-1}$ inoculation; $0.2-0-K e f i r:$ Kefir made from organic milk with $0.2 \mathrm{~g} 100 \mathrm{~g}^{-1}$ inoculation rate; 0.5 -0-Kefir: Kefir made from organic milk with $0.5 \mathrm{~g} 100 \mathrm{~g}^{-1}$ inoculation rate. Values are mean and bars show SD for $\mathrm{n}=6$.

\section{Acknowledgment}

The authors wish to thank Kadriye Tül, Nur Özyol and Tuba Nil Dengiz for technical assistance in labratory. GC-MS and HPLC in this work were supported by the T.R. Prime Ministry State Planning Organization (DPT) project (Project no: $02 \mathrm{~K}$ 120860).

\section{Research Highlights}

Organic milk kefir had high succinic, acetic, propyonic and pyruvic acid contents Increase in inoculation rate increased in acetaldehyde, ethanol and ethyl acetate Conventional milk kefir had high free fatty acids and benzene-containing compounds

High inoculation rate increased in proline, tyrosine, cysteine and valin levels Panelists liked organic milk kefir made using $0.2 \%$ kefir grains as inoculate.

\section{References}

1. Jianzhong Z, Xiaoli L, Hanhu J, Mingsheng D (2009) Analysis of the microflora in Tibetan kefir grains using denaturing gradient gel electrophoresis. Food Microbiol 26: 770-775. Link: https://goo.gl/y4xkXF

2. Angulo L, Lopez $E$ and Lema $C$ (1993) Microflora present in kefir grains of the Galician region (North-west of Spain). J Dairy Res 60: 263-267. Link: https:// goo.gl/0uMqd1

3. Güzel-Seydim Z, Seydim A, Greene A (2000b) Organic acids and volatile flavour components evolved during refrigerated storage of kefir. J Dairy Sci 83: 275-277. Link: https://goo.gl/pi3vDE

4. Beshkova DM, Simova ED, Frengova Gl, Simov Zl, Dimitrov ZHP (2003)
Production of volatile aroma compounds by kefir starter cultures. Int Dairy J 13: 529-535. Link: https://goo.gl/tu71eY

5. Aghlara A, Mustafa S, Manap YA, Mohamad R (2009) Characterization of headspace volatile flavor compounds formed during kefir production: application of solid phase microextraction. Int J Food Prop 12: 808-818. Link: https://goo.gl/9rYGbj

6. Grønnevik H, Falstad M, Narvhus JA (2011) Microbiological and chemical properties of Norwegian kefir during storage. Int Dairy J 21: 601-606. Link: https://goo.gl/vusFt

7. Farnworth E (2005) Kefir: a complex probiotic. Food Science and Technology Bulletin: Func Foods 2: 1-17. Link: https://goo.gl/b5s8yg

8. Irigoyen A, Arana I, Castiella M, Torre P, Ibáñez FC (2005) Microbiological, physicochemical, and sensory characteristics of kefir during storage. Food Chem 90: 613-620. Link: https://goo.gl/7Gxo0

9. AOAC (2003) Official Methods of Analysis. 17th edition. Association of Official Analytical Chemists. Arlington: VA, USA. Link: https://goo.gl/Tj8X2T

10. International Dairy Federation (1962) Determination of the protein content of milk. Brussels: IDF Standard $28 \mathrm{~A}$.

11. Fernández-Garcia E, McGregor JU (1994) Determination of organic acids during the fermentationand cold storage of yoghurt. J. Dairy Sci. 77: 29342939. Link: https://goo.gl/p0xd7r

12. Guler Z, Karaca F, Yetisir H (2013) Volatile compounds in the peel and flesh of cucumber (Cucumis sativus L) grafted onto bottle gourd (Lagenaria siceraria) rootstock. J Hort Sci Biotech 88:123-128. Link: https://goo.gl/ctxcwX

13. Guler Z, Gursoy-BalcI AC (2011) Evaluation of volatile compounds and free fatty acids in set types yogurts made of ewes', goats' milk and their mixture using two different commercial starter cultures during refrigerated storage. Food Chem 127: 1065-1071. Link: https://goo.gl/9mgJnl 
14. Aristoy M, Toldrá F (1991) Deproteinization techniques for HPLC amino acid analysis in fresh pork muscle and dry cured ham. J Agric and Food Chem 39:1792-1795. Link: https://goo.gl/a9x1i6

15. Coakes SJ, Steed LG, Ong C (2009) Analysis Without Anguish Using SPSS Version 170 for windows London, UK: John Willey \& Sons

16. Zajšek K, Goršek A, Kolar M (2013) Cultivating conditions effects on kefiran production by the mixed culture of lactic acid bacteria imbedded within kefir grains. Food Chem139: 970-977. Link: https://goo.gl/usXXeQ

17. Ozer D, Ozer BH (1999) Product of Eastern Europe and Asia. In R. K. Robinson (Ed.), Encyclopedia of Food Microbiology, Volume 2 (pp. 798-805), London: Academic Press.

18. Leite AM, Leite DC, Del Aguila EM, Alvares TS, Peixoto RS, et al. (2013) Microbiological and chemical characteristics of Brazilian kefir during fermentation and storage processes. J Dairy Sci 96:4149-4159. Link: https://goo.gl/uF559W

19. Lourens-Hattingh A, Viljoen BC (2001) Yogurt as probiotic carrier food. Int Dairy J 11: 1-17. Link: https://goo.gl/8vl00

20. Kamzolova SV, Yusupova Al, Dedyukhina EG, Chistyakova TI, Kozyreva TM, et al. (2009) Succinic acid synthesis by ethanol-grown yeasts. Food Technol Biotech 47:144-152. Link: https://goo.gl/c20WWk

21. McSweeney PLH, Sousa MJ (2000) Biochemical pathways for the production of flavour compounds in cheese during ripening: a review. Lait 80:293-324. Link: https://goo.gl/wSwUg3
22. Magalhães KT, Dragone G, de Melo Pereira GV, Oliveira JM, Domingues et al. (2011) Comparative study of the biochemical changes and volatile compound formations during the production of novel whey-based kefir beverages and traditional milk kefir. Food Chem 126: 249-253. Link: https:// goo.gl/PFrgZe

23. Collins YF, McSweeney PLH, Wilkinson MG (2003) Lipolysis and free fatty acid catabolism in cheese: a review of current knowledge. Int Dairy $\mathrm{J} 13$ : 841-866. Link: https://goo.gl/srvsG

24. Dimos A, Urbach G, Miller AJ (1996) Changes in flavor and volatiles of full and reduced fat Cheddar cheese during maturation. Int Dairy J 6: 981-995. Link: https://goo.gl/ThFTiV

25. Molimard P, Spinnler HE (1996) Compound involved in the flavor of surface mold-ripened cheeses: origins and properties. J Dairy Sci 79:169-184. Link:

26. Liutkevicius A, Sarkinas A (2004) Studies on the growth conditions and composition of kefir grains as a food and forage biomass. Dairy Sci Abst 66 : 903. Link: https://goo.gl/ULYz3H

27. Tamime AY, Robinson R K (2001) Yogurt Science and Technology. New York, USA: CRC Press. Pp.1-478. Link: https://goo.gl/oYMfS2

28. Simova E, Simov Z, Beshkova D, Frengova G, Dimitrov Z, et al. (2006) Amino acid profiles of lactic acid bacteria, isolated from kefir grains and kefir starter made from them. Int J Food Microbiol 107: 112 - 123. Link: https://goo.gl/ vjUqm1

29. Fernández M, Zúñiga M (2006) Amino acid catabolic pathways of lactic acid bacteria. Critical Rev Microbiol 32:155-183. Link: https://goo.gl/bZuPql

Copyright: (C) 2016 Güler Z, et al. This is an open-access article distributed under the terms of the Creative Commons Attribution License, which permits unrestricted use, distribution, and $r$ eproduction in any medium, provided the original author and source are credited. 